\title{
USE OF STANDARD LIGHT-SENSITIVE
}

PAPER FOR CALIBRATING CARBON ARCS USED IN TESTING TEXTILES

U.S. FOR COLORFASTNESS TO LIGHT EPARTMENT OF COMMERCE National

Bureau

Standards

$$
\begin{gathered}
Q C \\
100 \\
.457 \\
\text { no. 260-41 } \\
1972 \\
c .2
\end{gathered}
$$


The National Bureau of Standards ${ }^{1}$ was established by an act of Congress March 3, 1901. The Bureau's overall goal is to strengthen and advance the Nation's science and technology and facilitate their effective application for public benefit. To this end, the Bureau conducts research and provides: (1) a basis for the Nation's physical measurement system, (2) scientific and technological services for industry and government, (3) a technical basis for equity in trade, and (4) technical services to promote public safety. The Bureau consists of the Institute for Basic Standards, the Institute for Materials Research, the Institute for Applied Technology, the Center for Computer Sciences and Technology, and the Office for Information Programs.

THE INSTITUTE FOR BASIC STANDARDS provides the central basis within the United States of a complete and consistent system of physical measurement; coordinates that system with measurement systems of other nations; and furnishes essential services leading to accurate and uniform physical measurements throughout the Nation's scientific community, industry, and commerce. The Institute consists of a Center for Radiation Research, an Office of Measurement Services and the following divisions:

Applied Mathematics-Electricity-Heat-Mechanics-Optical Physics-Linac Radiation ${ }^{2}$ - Nuclear Radiation ${ }^{2}$ - Applied Radiation ${ }^{2}$-Quantum Electronics ${ }^{3}$ Electromagnetics ${ }^{3}$-Time and Frequency ${ }^{3}$ - Laboratory Astrophysics ${ }^{3}-$ Cryo- $^{2}$ genics ${ }^{3}$.

THE INSTITUTE FOR MATERIALS RESEARCH conducts materials research leading to improved methods of measurement, standards, and data on the properties of well-characterized materials needed by industry, commerce, educational institutions, and Government; provides advisory and research services to other Government agencies; and develops, produces, and distributes standard reference materials. The Institute consists of the Office of Standard Reference Materials and the following divisions:

Analytical Chemistry-Polymers-Metallurgy-Inorganic Materials-Reactor Radiation-Physical Chemistry.

THE INSTITUTE FOR APPLIED TECHNOLOGY provides technical services to promote the use of available technology and to facilitate technological innovation in industry and Government; cooperates with public and private organizations leading to the development of technological standards (including mandatory safety standards), codes and methods of test; and provides technical advice and services to Government agencies upon request. The Institute also monitors NBS engineering standards activities and provides liaison between NBS and national and internątional engineering standards bodies. The Institute consists of the following divisions and offices:

Engineering Standards Services-Weights and Measures--Invention and Innovation-Product Evaluation Technology-Building Research-Electronic Technology-Technical Analysis-Measurement Engineering-Office of Fire Programs.

THE CENTER FOR COMPUTER SCIENCES AND TECHNOLOGY conducts research and provides technical services designed to aid Government agencies in improving cost effectiveness in the conduct of their programs through the selection, acquisition, and effective utilization of automatic data processing equipment; and serves as the principal focus within the executive branch for the development of Federal standards for automatic data processing equipment, techniques, and computer languages. The Center consists of the following offices and divisions:

Information Processing Standards-Computer Information-Computer Services -Systems Development-Information Processing Technology.

THE OFFICE FOR INFORMATION PROGRAMS promotes optimum dissemination and accessibility of scientific information generated within NBS and other agencies of the Federal Government; promotes the development of the National Standard Reference Data System and a system of information analysis centers dealing with the broader aspects of the National Measurement System; provides appropriate services to ensure that the NBS staff has optimum accessibility to the scientific information of the world, and directs the public information activities of the Bureau. The Office consists of the following organizational units:

Office of Standard Reference Data-Office of Technical Information and Publications-Library-Office of International Relations. 


\section{hal Bureau of Standards}

DEC 197 \%

\section{ace.}

\section{Standard Reference Materials:}

\section{$260-41$}

172

\section{Use of Standard Light-Sensitive Paper For Calibrating Carbon Arcs Used in Testing Textiles For Colorfastness to Light}

Lawrence A. Wood and Paul J. Shouse

Institute for Materials Research

U.5. National Bureau of Standards

i.. Washington, D.C. 20234

i. Special publication no. $260-41$

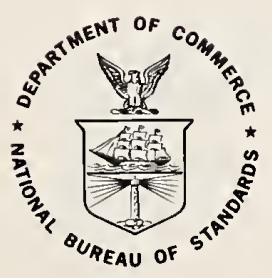

U.S. DEPARTMENT OF COMMERCE, Peter G. Peterson, Secretary NATIONAL BUREAU OF STANDARDS, Lawrence M. Kushner, Acting Director, 
Library of Congress Catalog Card Number: 72-600 192

National Bureau of Standards Special Publication 260-41

Nat. Bur. Stand. (U.S.), Spec. Publ. 260-41, 24 pages (Aug. 1972)

CODEN: XNBSAV

For sale by the Superintendent of Documents, U.S. Government Printing Office, Washington, D.C. 20402 (Order by SD Catalog No. C13.10:260-41). Price 30 cents. 


\section{PREFACE}

Standard Reference Materials (SRM's) as defined by the National Bureau of Standards are "well-characterized materials, produced in quantity, that calibrate a measurement system to assure compatability of measurement in the nation." SRM's are widely used as primary standards in many diverse fields in science, industry, and technology, both within the United States and throughout the world. In many industries traceability of their quality control process to the national measurement system is carried out through the mechanism and use of SRM's. For many of the nation's scientists and technologists it is therefore of more than passing interest to know the details of the measurements made at NBS in arriving at the certified values of the SRM's produced. An NBS series of papers, of which this publication is a member, called the NBS Special Publication - 260 Series is reserved for this purpose.

This 260 Series is dedicated to the dissemination of information on all phases of the preparation, measurement, and certification of NBS-SRM's. In general, much more detail will be found in these papers than is generally allowed, or desirable, in scientific journal articles. This enables the user to assess the validity and accuracy of the measurement processes employed, to judge the statistical analysis, and to learn details of techniques and methods utilized for work entailing the greatest care and accuracy. It is also hoped that these papers will provide sufficient additional information not found on the certificate so that new applications in diverse fields not foreseen at the time the SRM was originally issued will be sought and found.

Inquiries concerning the technical content of this paper should be directed to the author(s). Other questions concerned with the availability, delivery, price, and so forth will receive prompt attention from:

Office of Standard Reference Materials National Bureau of Standards Washington, D.C. 20234

J. Paul Cali, Chief Office of Standard Reference Materials 
CONTENTS

PAGE

1. INTRODUCTION . . . . . . . . . . . . . . . 1

2. NBS MASTER LAMP . . . . . . . . . . . . 3

3. LIGHT-SENSITIVE PAPER . . . . . . . . . . . . 4

4. STANDARD FADING HOURS $(\mathrm{SFH})$. . . . . . . . 6

5. EFFECT OF DEVIATIONS FROM STANDARD CONDITIONS . 7

5.1 BLACK-PANEL TEMPERATURE . . . . . . . . 7

5.2 HUMIDITY . . . . . . . . . . . 8

5.3 INTERMITTENT EXPOSURE . . . . . . . . 9

6. PROCEDURE FOR EXPOSURE . . . . . . . . . . . 9

7. RATING OF THE PAPERS AFTER EXPOSURE . . . . . . 10

7.I VISUAL ESTIMATION . . . . . . . . . . . . .

7.2 REFLECTANCE MEASUREMENTS . . . . . . . . . II

7.3 CALIBRATION BY OTHER PROPERTIES . . . . . .13

8. FREQUENCY OF CALIBRATION . . . . . . . . . . . 13

9. PROCEDURE FOR ORDERING PAPER AND BOOKLETS . . . . 15

10. REFERENCES . . . . . . . . . . . . . . . . . . 
NBS Spec. Publ. 260, Catalog of Standard Reference Materials, July 1970. 75 cents.* (Supersedes NBS Misc. Publ. 260, January 1968 and NBS Misc. Publ. 241, March 1962.)

NBS Misc. Publ. 260-1, Standard Reference Materials: Preparation of NBS White Cast Iron Spectrochemical Standards, June 1964. 30 cents. *

NBS Misc. Publ. 260-2, Standard Reference Materials: Preparation of NBS Copper-Base Spectrochemical Standards, October 1964. 35 cents. *

NBS Misc. Publ. 260-3, Standard Reference Materials: Metallographic Characterization of an NBS Spectrometric Low-Alloy Steel Standard, October 1964. 20 cents.* (Out of print).

NBS Misc. Publ. 260-4, Standard Reference Materials: Sources of Information on Standard Reference Materials, February 1965. 20 cents. * (Out of print).

NBS Misc. Publ. 260-5, Standard Reference Materials: Accuracy of Solution X-Ray Spectrometric Analysis of Copper-Base Alloys, March 1965. 25 cents.* (Out of print).

NBS Misc. Publ. 260-6, Standard Reference Materials: Methods for the Chemical Analysis of White Cast Iron Standards, July 1965. 4.5 cents. *

NBS Misc. Publ. 260-7, Standard Reference Materials: Methods for the Chemical Analysis of NBS Copper-Base Spectrochemical Standards, October 1965.60 cents. *

NBS Misc. Publ. 260-8, Standard Reference Materials: Analysis of Uranium Concentrates at the National Bureau of Standards, December 1965.60 cents. * (Out of print).

NBS Misc. Publ. 260-9, Standard Reference Materials: Half Lives of Materials Used in the Preparation of Standard Reference Materials of Nineteen Radioactive Nuclides Issued by the National Bureau of Standards, November 1965. 15 cents.*

NBS Misc. Publ. 260-10, Standard Reference Materials: Homogeneity Characterization on NBS Spectrometric Standards II: Cartridge Brass and Low-Alloy Steel, December 1965. 30 cents. *

NBS Misc. Publ. 260-11, Standard Reference Materials: Viscosity of a Standard Lead-Silica Glass, November 1966. 25 cents.*
NBS Misc. Publ. 260-12, Standard Reference Materials: Homogeneity Characterization of NBS Spectrometric Standards III : White Cast Iron and Stainless Steel Powder Compact, September 1966. 20 cents.*

NBS Misc. Publ. 260-13, Standard Reference Materials: Mossbauer Spectroscopy Standard for the Chemical Shift of Iron Compounds, July 1967.40 cents.*

NBS Misc. Publ. 260-14, Standard Reference Materials: Determination of Oxygen in Ferrous Materials - SRM 1090, 1091, and 1092, September 1966.30 cents.*

NBS Misc. Publ. 260-15, Standard Reference

Materials: Recommended Method of Use of Standard Light-Sensitive Paper for Calibrating Carbon Arcs Used in Testing Textiles for Colorfastness to Light, June 1967. 20 cents.* NBS Spec. Publ. 260-16, Standard Reference Materials: Homogeneity Characterization of NBS Spectrometric Standards IV: Preparation and Microprobe Characterization of W-20\% Mo Alloy Fabricated by Powder Metallurgical Methods, January 1969. 35 cents.*

NBS Spec. Publ. 260-17, Standard Reference Materials: Boric Acid; Isotopic and Assay Standard Reference Materials, February 1970.65 cents.*

NBS Spec. Publ. 260-18, Standard Reference Materials: Calibration of NBS Secondary Standard Magnetic Tape (Computer Amplitude Reference) Using the Reference Tape Amplitude Measurement "Process A", November 1969.50 cents. ${ }^{*}$

NBS Spec. Publ. 260-19, Standard Reference Materials: Analysis of Interlaboratory Measurements on the Vapor Pressure of Gold (Certification of Standard Reference Material 745), January 1970.30 cents.*

NBS Spec. Publ. 260-20, Standard Reference Materials: Preparation and Analysis of Trace Element Glass Standards. (In preparation)

NBS Spec. Publ. 260-21, Standard Reference Materials: Analysis of Interlaboratory Measurements on the Vapor Pressures of Cadmium and Silver, January 1971. 35 cents.*

NBS Spec. Publ. 260-22, Standard Reference Materials: Homogeneity Characterization of Fe-3Si Alloy, February 1971. 35 cents.*

NBS Spec. Publ. 260-23, Standard Reference Materials: Viscosity of a Standard Borosilicate Glass, December 1970. 25 cents.* 
NBS Spec. Publ. 260-24, Standard Reference Materials: Comparison of Redox Standards, January 1972. \$1.*

NBS Spec. Publ. 260-25, Standard Reference Materials: A Standard Reference Material Containing Nominally Four Percent Austenite, February 1971.30 cents. *

NBS Spec. Publ. 260-26, Standard Reference Materials: National Bureau of StandardsU.S. Steel Corporation Joint Program for Determining Oxygen and Nitrogen in Steel, Fcbruary 1971.50 cents. *

NBS Spec. Publ. 260-27, Standard Reference Materials: Uranium Isotopic Standard Reference Materials, April 1971.\$1.25.*

NBS Spec. Publ. 260-28, Standard Reference Materials: Preparation and Evaluation of SRM's 481 and 482 Gold-Silver and GoldCopper Alloys for Microanalysis, August 1971. \$1.*

NBS Spec. Publ. 260-29, Standard Reference Materials: Calibration of NBS Secondary Standard Magnetic Tape (Computer Amplitude Reference) Using the Refercnce Tape Amplitude Measurement "Process A-Model 2", June 1971.60 cents. *

NBS Spec. Publ. 260-30, Standard Reference Materials: Standard Samples Issued in the USSR (A Translation from the Russian), June 1971. \$1.*

NBS Spec. Publ. 260-31, Standard Reference Materials: Thermal Conductivity of Electrolytic Iron SRM 734 from 4 to $300 \mathrm{~K}$, November 1971.35 cents. *

NBS Spec. Publ. 260-32, Standard Reference Materials: The Cooperative Study of Temperature Scale Standards for DTA by ICTA and NBS. (In preparation)
NBS Spec. Publ. 260-33, Standard Reference Materials: Comparison of Original and Supplemental SRM 705, Narrow Molecular Weight Distribution Polystyrene, H. L. Wagner, May 1972. 35 cents. *

NBS Spec. Publ. 260-34, Standard Reference Materials: Thermoelectric Voltage, April 1972.40 cents. *

NBS Spec. Publ. 260-35, Standard Reference Materials: Thermal Conductivity of Austenitic Stainless Steel, SRM 735 from 5 to $280 \mathrm{~K}$, April 1972. 35 cents. *

NBS Spec. Publ. 260-36, Standard Reference Materials: A Referee Method for the Determination of Calcium in Serum. SRM 736, May 1972. \$1.25.*

NBS Spec. Publ. 260-37, Standard Reference Materials: Methods of Analysis of NBS Clay Standards, June 1972. 75 cents. *

NBS Spec. Publ. 260-38, Standard Reference Materials: Preparation and Calibration of Standards of Spectral Specular Reflectance, May 1972.60 cents. ${ }^{*}$

NBS Spec. Publ. 260-39, Standard Reference Materials: The Eddy Current Decay Method for Resistivity Characterization of HighPurity Metals, May 1972. 55 cents.*

NBS Spec. Publ. 260-40, Standard Reference Materials: Selection of Thermal Analysis Temperature Standards Through a Cooperative Study (SRM 758, 759, 760). (In preparation)

NBS Spec. Publ. 260-41, Standard Reference Materials: Use of Standard Light-Sensitive Paper for Calibrating Carbon Ares used in Testing Textiles for Colorfastness to Light. (In preparation)

*Send order with remittance to: Superintendent of Documents, U.S. Government Printing Office, Washington, D.C. 20402. Remittance from foreign countries should include an additional one-fourth of the purchase price for postage. 
USE OF STANDARD LIGHT-SENSITIVE PAPER FOR CALIBRATING

CARBON ARCS USED IN TESTING TEXTILES FOR COLORFASTNESS TO LIGHT

by

Lawrence A. Wood and Paul J. Shouse

Institute for Materials Research

National Bureau of Standards

Washington, D. C. 20234

The use of NBS Light-Sensitive Paper and NBS Booklets of Standard Faded Strips in the standardization of carbon arcs is described. These lamps are used to determine the fading characteristics and degradation of textiles and other materials when subjected to visible and ultraviolet radiation. The light-sensitive paper is useful in calibrating the arcs in terms of NBS Standard Fading Hours (SFH) or equivalent exposure in the NBS Master Carbon-Arc Lamp.

Key words: Carbon-arcs, standardization of; color-fastness, testing of; fading tests, standardization; light-sensitive paper; paper, light-sensitive; textiles, fading of.

\section{INTRODUCTION}

Carbon-arc lamps are widely used for testing colorfastness and stability of materials to visible and ultraviolet radiation. The variability of the output of a given lamp and the differences between lamps have led to the extensive use of standard reference materials that undergo measurable changes when exposed to this radiation.

The American Association of Textile Chemists and Colorists, following work begun in 1931 or earlier, developed a set of 8 blue wool standards covering various ranges up to 640 hours of exposure. The steps are logarithmic, each standard requiring approximately twice the exposure of the previous one to obtain equivalent fading. These are in extensive use in testing the fading of textiles. One of these, denoted as $\mathrm{L}-4$, has been the subject of a detailed study 
[1] which showed that for carbon-arc exposures near 20 hours the standard deviation of a single instrumental measurement of color difference corresponded to about 3 standard Fading Hours (SFH). A group of 9 observations near $20 \mathrm{SFH}$ would then be expected to range from 15.5 to $24.5 \mathrm{SFH}$, since statistical theory predicts that the range is approximately the product of the standard deviation by the square root of the number of observations. This precision is adequate for its intended purpose of placing an unknown specimen in the proper step of the 8-step logarithmic scale of exposures, but is not good enough to serve as a basis for calibrating and adjusting the arcs.

Consequently the National Bureau of Standards, following research work begun about 1940 [2], developed and issued standard light sensitive-paper, for which during a given exposure the change in spectral reflectance (at various wavelengths) is from 10-20 times that of the wool [1] and the change in luminous reflectance, or tristimulus $\underline{Y}$ value, is 15-20 times that of the wool. The precision of determination of exposure is found to be about 4-fold better than that with the wool. A group of 9 observations on the paper near $20 \mathrm{SFH}$ is expected to range from about 18.8 to 21.2 SFH. The period of 20-24 hours is particularly important because it corresponds approximately to the life of one set of carbons.

In calibrating a given carbon arc the paper is exposed and then compared with six strips of the paper which have been exposed for different known periods of time in the NBS Master Carbon-Arc Lamp. The calibration procedure outlined below is the same as that currently specified in Appendix $B$ of AATCC Test Method 16A-1971 (Technical Manual, American Association of Textile Chemists and Colorists, P.O. Box 12215, Research Triangle Park, North Carolina 27709). 
The present NBS Master Iamp is an Atlas Electric Device type SMC-R enclosed carbon-arc Fade-Ometer operated on alternating current.* The arc voltage is $120-145 \mathrm{~V}$ and the current 15-17 A (ranges specified by the manufacturer). The construction of the unit is almost identical with that of the Fade-Ometer described in detail by Boor and Trucker [3]. It uses No. 70 solid carbons and No. 20 cored carbons. The solid carbon is placed in the upper holder and the cored carbon in the lower holder for one run, and these positions are reversed for the next run. The arc is enclosed in a special Pyrex glass globe (No. 9200PX).

The specimems are exposed (without backing) in a rack $20 \mathrm{in.}(50.8 \mathrm{~cm})$ in diameter rotating at $3 \mathrm{rpm}$.

\section{*Footnote:}

Manufactured by Atlas Electric Devices Co., $4114 \mathrm{~N}$. Ravenswood Avenue, Chicago, Illinois 60613.

Certain commercial equipment and instruments are identified here and elsewhere in this publication in order to adequately specify the experimental procedure. In no case does such identification imply recommendation or endorsement by the National Bureau of Standards, nor does it imply that the equipment or instruments identified are necessarily the best available for the purpose. 
A black panel of enameled metal is placed in one of the specimen positions in the rack. The black-panel temperature is held at $150 \pm 5^{\circ} \mathrm{F}\left(65.6 \pm 2^{\circ} \mathrm{C}\right)$ by dampers which automatically control the ratio of exit air to recirculated air. The control element for the dampers is in the stream of humidified inlet air and is manually set to maintain the black-panel temperature. It should be noted that the American Association of Textile Chemists and Colorists specifies a black-panel temperature of $145 \pm 5^{\circ} \mathrm{F}\left(63 \pm 3^{\circ} \mathrm{C}\right)$ in AATCC Test Method 16A-1971.

The variation during a single run seldom exceeds $\pm 4^{\circ} \mathrm{F}$. The ambient temperature $\left(77^{\circ} \mathrm{F}, 25^{\circ} \mathrm{C}\right.$ ) and humidity (45\% $\mathrm{RH}$, Dew Point $54^{\circ} \mathrm{F}, 12^{\circ} \mathrm{C}$ ) and size of our present laboratory are such that under these conditions the temperature of the exit air is usually $118 \pm 2^{\circ} \mathrm{F}\left(47.8 \pm 1^{\circ} \mathrm{C}\right)$.

Moisture is added to the circulating air by water sprayed from a rotating disk to raise the relative humidity of the exit air to $30 \%$ at the ary-bulb temperature of $118^{\circ} \mathrm{F}$. A bimetallic thermostat responding to wet-bulb temperature starts and stops the rotating disk. The humidity is controlled by automatically maintaining the wet-bulb temperature at a desired value $\left(88^{\circ} \mathrm{F}, 31^{\circ} \mathrm{C}\right.$ in the present instance). The dew point of the exit air under these conditions is $79^{\circ} \mathrm{F}\left(26^{\circ} \mathrm{C}\right)$. It would be quite inconvenient to maintain a higher humidity, since a dew point higher than room temperature gives rise to condensation difficulties when the air is allowed to cool from $118^{\circ} \mathrm{F}$ to room temperature.

\section{LIGHT-SENSITIVE PAPER}

Successive lots of light-sensitive paper have been issued by the National Bureau of Standards since about 1945 [2]. They are now sold as items in the NBS standard Reference Materials program and carry the designations SRM 700 for the unexposed paper and SRM 701 for the booklets 
of six strips which have been exposed for stated periods of time in the NBS Master Lamp. The particular lot is designated by a letter following the SRM number. Thus, SRM 700a and SRM 70la were issued in June 1965, and were followed by SRM 700b and SRM 70lb in June 1967. The most recent lot is SRM $700 \mathrm{c}$ and SRM 70lc, issued in November 1971. Lots differ slightly both in the reflectance of the unexposed paper and in the rate of fading. Consequently the paper from a given lot can be used only with the booklet from the same lot. Each order of booklet and package of paper is accompanied by a Certificate of Calibration including the numerical values characteristic of the particular lot.

The paper, made in the National Bureau of Standards paper mill, contains the direct azo dye Benzo Azurine G, Colour Index Direct Blue [eight] No. 24140. The unexposed paper is supplied in pieces $2-5 / 8$ by $3-1 / 4$ inches. Each booklet contains 6 paper strips (about $1-1 / 2$ by 3 inches) which have been faded by exposure for different times in the NBS Master Carbon Arc described in the preceding section. To facilitate production the booklets are assembled in four different series with the following nominal values:

Series A $-6,8,10,14,18, \quad$ and 22SFH;
Series $B-7,1,11,15,19, \quad$ and 23SFH;
Series $C-8,10,12,16,20$, and $24 \mathrm{SFH} ;$

and

Series D $-9,11,13,17,21$, and $25 \mathrm{SFH}$.

The different series have the same-sized intervals, and the booklets of each series are fully equivalent to each other. 
The quantitative basis for establishing a unit standard fading hour (SFH) at the National Bureau of Standards before 1950 has been discussed in detail in a previous publication [1]. A "Fade-Ometer Hour" had already been used for some years in the textile industry, and $20 \mathrm{SFH}$ was defined as being equivalent to 20 clock hours $(\mathrm{CH})$ of exposure in the Atlas Type FDA-R Carbon-Arc Fade-Ometer, the type in most general use at the time. Since February 1949, every effort has been made by repeated comparisons involving lightsensitive paper to keep constant the dosage of carbon arc radiation represented by $20 \mathrm{SFH}$.

In order to attain this aim, over the years repeated observations have been made of the color changes found in a given lot of paper for 20 hours of operation of the NBS Master Carbon-Arc Lamp. No significant differences have been found. Each new lot of paper has been compared carefully with one or more of the preceding lots at the time it has been introduced. The exposures of the new lot have been expressed in terms of the SFH defined by the preceding lots.

Over the years the conditions of operation of the master carbon-arc lamp have been controlled and specified with progressively increasing detail and some changes in the arc have been made. As a result, it is found that a 20-hour exposure in the present NBS Master Lamp under the conditions of operation given above causes fading of the ligh-sensitive paper by an amount equivalent to about $18 \mathrm{SFH}$.

Defining a severity factor $\underline{F}$ as the ratio of standard fading hours $\underline{\mathrm{SFH}}$ to clock hours $\underline{\mathrm{CH}}$, one finds that $\underline{\mathrm{F}}$ for the NBS Master Lamp is about 0.9 at $20 \mathrm{CH}$. It is possible to vary the severity factor for the carbon arc somewhat by changing the arc voltage by using a different transformer 
tap, but only a limited range of adjustment is possible. The severity factor can be altered markedly by deviations from the standard conditions of specimen distance, humidity, and black-panel temperatures. It should be kept in the range $0.9 \pm 0.1$ at $20 \mathrm{CH}$. The severity factor generally decreases with decreasing exposure time. The severity is obviously lower than that employed prior to 1950 (when $\left.F_{-}=1.0\right)$. The reduction is probably due chiefly to the lowering of the recommended effective black-panel temperature from its early value of about $165^{\circ} \mathrm{F}\left(73.9^{\circ} \mathrm{C}\right.$ ) to $150^{\circ} \mathrm{F}\left(65.6^{\circ} \mathrm{C}\right)$.

5. EFFECT OF DEVIATIONS FROM STANDARD CONDITIONS

In calibrations at the National Bureau of Standards all work is done under the standard conditions already described. It is of interest to examine the effects of several deviations from these standard conditions.

\subsection{BLACK-PANEL TEMPERATURE}

A recent unpublished NBS study of the fading of the paper at lower black-panel temperatures (while maintaining $30 \% \mathrm{RH}$ for the exit air) shows a reduction in the number of SFH at the rate of about $0.3 \mathrm{SFH}$ for each Fahrenheit degree. Thus if a 20-hour exposure gives $18 \mathrm{SFH}$ at 150F, about $16.5 \mathrm{SFH}$ will be found at $145^{\circ} \mathrm{F}$ and about $12.9 \mathrm{SFH}$ at $133^{\circ} \mathrm{F}$. The corresponding severity factors are $0.9,0.83$, and 0.65 , respectively. The last temperature $\left(133^{\circ} \mathrm{F}, 56.1^{\circ} \mathrm{C}\right.$ ) is the lowest black-panel temperature attainable without increasing the cooling facilities in the room where our arc is located.

Similar observations regarding the effect of temperature on the fading of NBS Light-Sensitive Paper Lot 1554 were reported by Boor and Trucker [3] . 
In the NBS Master Lamp the relative humidity is maintained at $30 \%$ at the temperature of the exit air, usually about $118^{\circ} \mathrm{F}$. This is accomplished by adding moisture to the air passing over the specimens. It has been pointed out that the dew point is an important parameter in these considerations [4]. The dew point under these conditions is about $79^{\circ} \mathrm{F}$. Reported values of dew point and relative humidity appreciably higher than those just mentioned are questionable, because measurement inaccuracies almost always lead to spuriously high values of humidity. Furthermore, if no condensation is observed as the exit air cools to room temperature, the dew point must be below room temperature. On the other hand, if condensation is observed, the presence of liquid water droplets can cause serious experimental difficulties.

If the lamp does not have provision for adding moisture, the dew point of the air around the specimens will be approximately the same as that of the laboratory. Unless the laboratory humidity is controlled, the dew point may vary from a maximum of perhaps $79^{\circ} \mathrm{F}$ on a very humid summer day to $10^{\circ} \mathrm{F}$ or less during the winter. The corresponding range of relative humidity when the air is heated to $118^{\circ} \mathrm{F}$ without the addition of moisture is from $30 \%$ to about $2 \%$.

The fading of the paper, as well as that of most textiles, is considerably reduced as the humidity is lowered below the standard condition of $30 \%$ at exit-air temperature. Some indication of the magnitude of this effect can be noted from the results of Boor and Trucker [3] on paper from Lot 1554. The reduction in fading is particularly great when the relative humidity falls below $20 \%$ 
The light-sensitive paper, as well as many textiles, fades more in a given time if exposed intermittently than if exposed continuously, probably because of an increase in relative humidity of the air and moisture content of the paper while the lamp is shut off, with more rapid fading when it is first turned on again. It is therefore necessary to begin tests with a fresh set of carbons in the lamp and to avoid shut-downs.

\section{PROCEDURE FOR EXPOSURE}

Mount a piece of unexposed light-sensitive paper in a specimen holder of the lamp without backing and place it in the lamp at the time it is started. The side of the paper facing the arc should be the one containing no printing. Furthermore, the paper should be placed so that the printed matter is not immediately back of the portion of the strip which is being exposed. Vacant positions in the specimen holder should be filled with dummy specimens to reduce variations in reflections and air currents.

At the end of the run remove the strip and allow it to stand in the dark at room temperature for at least 2 hours in order for it to cool and to regain its normal moisture from the air. If the fading is to be judged only visually, trim off and discard the unexposed edges of the paper and of the strips in the booklets as they may affect the judgment of the fading. For instrumental measurements the edges should remain attached for enhanced ease of handling during the measurements. 
7. RATING OF THE PAPERS AFTER EXPOSURE

\subsection{Visual Estimation}

Trim off and discard the unexposed edges of the paper, as already mentioned, so that the exposed paper may be placed immediately adjacent to the standard faded strips in the booklet. To make a visual comparison, hold the booklet in one hand, allow the pages to flip open one after another, rear cover first, and slip the exposed paper under one standard faded strip after another, being careful to have the standard strip superimposed closely upon the exposed paper with the long dimension of the two papers in the same direction. Make the comparison in the light from a daylight fluorescent lamp, or equivalent source, with illumination of 50 foot candles or more on the papers. The plane of the incident and reflected rays should be perpendicular to the long edge (machine direction) of the paper and booklet. The incident light should strike the paper at an angle of $45^{\circ}$, and the angle of viewing should be perpendicular to the surface of the paper. Avoid touching the surfaces of the exposed paper and the standard strips with the fingers, as the paper is sensitive to moisture and is easily soiled. From the comparison, estimate the exposure (to the nearest Standard Fading Hour) that would duplicate the fading of the test piece. For example, if the color of the test piece was considered to be mid-way between those of the standard strips labelled 16 and $20 \mathrm{SFH}$ in the booklet, the estimated value would be $18 \mathrm{SFH}$. If the test piece had been exposed for 20 hours, the severity factor $\mathrm{SFH} / \mathrm{CH}$ would then be $18 / 20=0.9$, the value recommended for normal operation of a carbon arc. The exposure in SFH at other times would then be taken as 0.9 of the time in clock hours.

The severity factor for the carbon arc should normally be kept between 0.8 and 1.0 at $20 \mathrm{cH}$. If it is found to be 
outside this range, change of the transformer tap or other adjustments should be made until this condition is attained.

In making preliminary comparisons of faded papers and standard faded strips, it is permissible to breathe on the paper momentarily to increase its moisture content. Final comparisons, however, should be made after the paper has been conditioned overnight or longer in the dark in air at $50 \%$ relative humidity at room temperature.

\subsection{REFLECTANCE MEASUREMENTS}

Although the paper and booklets were originally designed for simple visual estimation of the fading of test strips without the use of any accessories other than the eye, greater precision can be obtained by the use of an instrument measuring a property which changes with exposure. The property used at the National Bureau of Standards in evaluating the standard faded strips in the booklets is the $45^{\circ}, 0^{\circ}$ luminous-directional reflectance factor $R_{d}$ as measured with a green filter with a Hunter Color and Color Difference Meter (Gardner type) [5]. This is equal to the tristimulus value $\underline{Y}$. As with the visual estimation, the plane of the incident and reflected rays should be perpendicular to the long edge of the paper. Iikewise the incident light should strike the paper at an angle of $45^{\circ}$, as the reflectance normal to the surface is measured. The individual numerical value found at the time of preparation of each strip in the booklet is written in ink on the strip itself. The corresponding exposure (to the nearest $0.1 \mathrm{SFH}$ ) may be obtained from this value by interpolation in the table or graph furnished with the Certificate of Calibration for the particular lot of paper. In this manner the exposure of the standard faded strips can be fixed much more accurately. Their position in the booklet indicates the exposure only to the nearest unit SFH. 
The papers may change in reflectance on further exposure to light, heat, humidity or by mishandling or soiling.

Reflectance measurements on different instruments often show appreciable differences, even when measuring the same piece of exposed paper. Differences in reflectance readings can arise from differences in geometry of incident and viewing light beams, linearity of photometric scales, spectral sensitivity of the photocell, spectral transmittance of filters, and similar causes.

Reflectance measurements are made with the paper against a black background with the machine direction of the paper perpendicular to the plane of the incident and reflected rays. The machine direction (grain) of the paper lies along the longer side of both the unexposed paper and the standard strips in the booklet.

Most reflectometers yielding tristimulus $\underline{Y}$ values can be adjusted, if necessary, to make their readings agree with those shown in ink on the standard faded strips. For repeated standardizations a porcelain plaque of about the same. spectral reflectance as the exposed paper is recommended in order to avoid repeated handling of the paper.

Some reflectometers have a measurement precision that permits readings to four significant figures, as shown in the graph and table contained in the Certificate of Calibration. However, a comparison of reflectance measurements, on single strips given the same exposure shows a standard deviation of about 0.002 . This corresponds to about $0.8 \mathrm{SFH}$ near $20 \mathrm{SFH}$ and about $0.7 \mathrm{SFH}$ near $6 \mathrm{SFH}$.

If the user has available an instrument measuring reflectance and if the values observed with the six standard faded strips agree with or can be adjusted to agree with the values of $\underline{Y}$ written in ink on each strip, the instrument is in agreement with the one at the National Bureau of Standards. Consequently the graph and table 
given in the Certificate of Calibration can be utilized to obtain SFH for any test strip exposures.

\subsection{CALIBRATION BY OTHER PROPERTIES}

If the agreement just mentioned can not be obtained, or if the available instrument measures some property of the paper other than the tristimulus value $\underline{Y}$, the standard faded strips may still be used to calibrate this instrument. The property, presumably an optical property, can be any one which changes quantitatively with exposure. In this case a measurement is made on each of the six standard faded strips. The values found with the user's instrument are plotted as a function of the exposure of the standard strips in SFH (obtained from the reflectance marked on each strip) to obtain a six-point calibration curve for the property measured. When the user's instrument is calibrated in this manner, the same number of $\mathrm{SFH}$ should be obtained from a newly-exposed test strip of paper as would have been obtained if the calibration had been made in terms of any other property, including specifically the tristimulus $\underline{Y}$ value used at the National Bureau of Standards.

\section{FREQUENCY OF CALIBRATION}

Many laboratories always expose one or more strips of paper along with the textile specimens under test, thus obtaining a calibration every time the arc is operated. This is desirable since the fading rate of a carbon arc lamp may change from day to day or even during a test.

If the paper is not used during every run, a definite schedule for calibration at fixed intervals, should be developed by each user in accordance with his own requirements. Certainly the arc should be recalibrated whenever a new lot of carbons is put into use or any other 
significant change is made. The more frequently checks are made, the greater will be the assurance that the lamp is performing as desired.

For obtaining exposures near to a desired number of $\mathrm{SFH}$, duplicate strips of paper may be used, so that a preliminary value of the severity factor may be obtained from one strip before the estimated end of the run. The following instructions illustrate the procedure for obtaining an exposure of $20 \mathrm{SFH}$.

Place the textile specimen and two (or more if desired) pieces of the paper in the lamp at the same time, side by side. Remove one of the papers from the lamp about 4 hours before the estimated end of the test, noting the time. Allow this paper to stand in the dark at room temperature for 2 hours; compare the fading with that of the standard faded strips; and obtain the severity factor for converting clock hours to SFH as already outlined. Use this factor to calculate the time in clock hours to give the desired number of SFH at the end of the test.

The piece of paper left in the lamp with the textile will have received the same radiant-energy exposure as the textile at the end of the test. The actual exposure in SFH at the end of the test will then be obtained by rating the fading of this paper with the standard faded strips in the booklet. The result can be used as evidence that the test was as desired or sufficiently near to it, or that the test must be repeated.

For long exposures, a succession of papers will have to be used and the number of standard Fading Hours shown by them added together to obtain the total exposure. In making such tests, the paper should be changed with each change of carbons. 
9. PROCEDURE FOR ORDERING PAPER AND BOOKLETS

Different issues of the light-sensitive paper have different fading rates. Consequently, the booklets of standard faded strips and the fading curve supplied in the Certificate of Calibration for any one issue of unexposed paper apply to that issue only; therefore booklets and unexposed paper of the same issue should be used together. The lower case letter at the end of the standard sample number indicates the issue of the standard sample. The booklet of standard fading strips No. 70lc should be used with unexposed paper No. 700c. It cannot be used with No. $700 b$ or any earlier issue of the paper. However, when the supply of unexposed paper No. $700 \mathrm{c}$ at NBS becomes exhausted, a new issue will be supplied as standard Reference Material 700d. It will then become necessary for the customer to order a new booklet of standard faded strips No. 70ld to be used with the new issue of paper. This is unavoidable because it is not possible at present to control the manufacture of the paper so that all of the issues of paper are exactly the same with regard to fading rate.

The unexposed paper cannot be used satisfactorily without the booklet of standard faded strips because of differences in measuring instruments, as outlined earlier. This publication, explaining the use of the paper and booklet, and a Certificate of Calibration accompany each shipment of a sample of the unexposed paper or booklet of standard faded strips. They will be sent separately, free, on request.

Order by standard Reference Material Number (e.g., 700c for the unexposed paper; $701 \mathrm{c}$ for the booklet of standard faded strips). Address orders to: 
Office of Standard Reference Materials National Bureau of Standards Washington, D. C. 20234

Attention: Standard Reference Materials Unit

Prices and terms of purchase are given in NBS Miscellaneous Publication 260, "Catalog and Price List of Standard Reference Materials Issued by the National Bureau of Standards". 
1] Wood, L. A., Shouse, P. J., and Passaglia, E., "How just appreciable fading of AATCC $\mathrm{L}-4$ wool standard is related to exposure time", Textile Chemist and Colorist $\underline{2}$, No. $11,28 / 182(1970)$.

[2] Launer, H. F., "Light-sensitive papers as controls for testing textile colorfastness and stability of materials under arc-lamp exposure", J. Res. Nat. Bur. Stand. 41,169 (1948).

[3] Boor, L. and Trucker, S. L., "An improved Fade-Ometer", ASTM Bulletin No. 189, p. 38, April 1953.

[4] Wood, Lawrence A., "The use of dew-point temperature in humidity calculations", J. Res. Nat. Bur. Stand. 74C, 117 (1970).

[5] Hunter, Richard S., "Photoelectric color-difference meter", J. Optical Soc. Am. 48, 985 (1958). 
FORM NBS-114A (1.71)

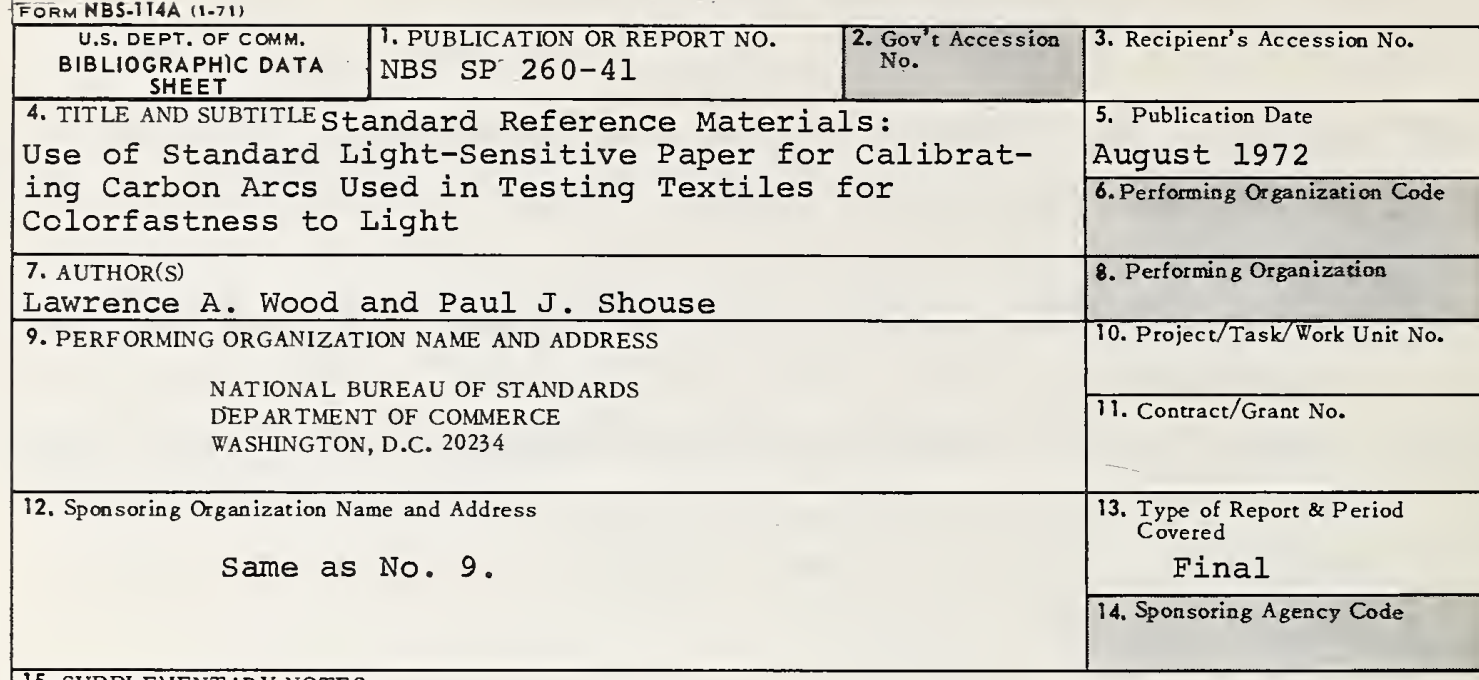

\section{SUPPLEMENTARY NOTES}

16. ABSTRACT (A 200 -word or less factual summary of most significant information. If document includes a significant bibliography or literature survey, mention it here.)

The use of NBS Light-Sensitive Paper and NBS Booklets of Standard Faded strips in the standardization of carbon arcs is described. These lamps are used to determine the fading characteristics and degradation of textiles and other materials when subjected to visible and ultraviolet radiation. The light-sensitive paper is useful in calibrating the arcs in terms of NBS Standard Fading Hours (SFH) or equivalent exposure in the NBS Master Carbon-Arc Lamp.

17. KEY WORDS (Alphabetical order, separated by semicolons) Carbon-arcs, standardization of ; color-fastness, testing of; fading tests, standardization; light-sensitive

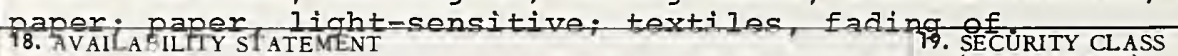

Q UNL IMITED.

FOR OFFICIAL DISTRIBUTION. DO NOT RELEASE TO NTIS. (THIS REPORT)

UNCL ASSIF IED

20. SECURITY CLASS (THIS PAGE)

UNCL ASSIFIED
21. NO. OF PAGES

24

22. Price

30 cents 
PERIODICALS

JOURNAL OF RESEARCH reports National Bureau of Standards research and development in physics, mathematics, and chemistry. Comprehensive scientific papers give complete details of the work, including laboratory data, experimental procedures, and theoretical and mathematical analyses. Illustrated with photographs, drawings, and charts. Includes listings of other NBS papers as issued.

Published in two sections, available separately:

\section{- Physics and Chemistry}

Papers of interest primarily to scientists working in these fields. This section covers a broad range of physical and chemical research, with major emphasis on standards of physical measurement, fundamental constants, and properties of matter. Issued six times a year. Annual subscription: Domestic, $\$ 9.50 ; \$ 2.25$ additional for foreign mailing.

\section{- Mathematical Sciences}

Studies and compilations designed mainly for the mathematician and theoretical physicist. Topics in mathematical statistics, theory of experiment design, numerical analysis, theoretical physics and chemistry, logical design and programming of computers and computer systems. Short numerical tables. Issued quarterly. Annual subscription: Domestic, \$5.00; $\$ 1.25$ additional for foreign mailing.

\section{TECHNICAL NEWS BULLETIN}

The best single source of information concerning the Bureau's measurement, research, developmental, cooperative, and publication activities, this monthly publication is designed for the industry-oriented individual whose daily work involves intimate contact with science and technology-for engineers, chemists, physicists, research managers, product-development managers, and company executives. Includes listing of all NBS papers as issued. Annual subscription: Domestic, $\$ 3.00 ; \$ 1.00$ additional for foreign mailing.

\section{Bibliographic Subscription Services}

The following current-awareness and literaturesurvey bibliographies are issued periodically by the Bureau: Cryogenic Data Center Current Awareness Service (weekly), Liquefied Natural Gas (quarterly), Superconducting Devices and Materials (quarterly), and Electromagnetic Metrology Current Awareness Service (monthly). Available only from NBS Boulder Laboratories. Ordering and cost information may be obtained from the Program Information Office, National Bureau of Standards, Boulder, Colorado 80302 .

\section{MONPERIODICALS}

Applied Mathematics Series. Mathematical tables, manuals, and studies.

Building Science Series. Research results, test methods, and performance criteria of building materials, components, systems, and structures.

Handbooks. Recommended codes of engineering and industrial practice (including safety codes) developed in cooperation with interested industries, professional organizations, and regulatory bodies.

Special Publications. Proceedings of NBS conferences, bibliographies, annual reports, wall charts, pamphlets, etc.

Monographs. Major contributions to the technical literature on various subjects related to the Bureau's scientific and technical activities.

National Standard Reference Data Series. NSRDS provides quantitative data on the physical and chemical properties of materials, compiled from the world's literature and critically evaluated.

Product Standards. Provide requirements for sizes, types, quality, and methods for testing various industrial products. These standards are developed cooperatively with interested Government and industry groups and provide the basis for common understanding of product characteristics for both buyers and sellers. Their use is voluntary.

Technical Notes. This series consists of communications and reports (covering both other-agency and NBS-sponsored work) of limited or transitory interest.

Federal Information Processing Standards Publications. This series is the official publication within the Federal Government for information on standards adopted and promulgated under the Public Law 89-306, and Bureau of the Budget Circular A-86 entitled, Standardization of Data Elements and Codes in Data Systems.

Consumer Information Series. Practical information, based on NBS research and experience, covering areas of interest to the consumer. Easily understandable language and illustrations provide useful background knowledge for shopping in today's technological marketplace.

\section{CATALOGS OF NBS PUBLICATIONS}

NBS Special Publication 305, Publications of the NBS. 1966-1967. When ordering, include Catalog No. C13.10:305. Price $\$ 2.00 ; 50$ cents additional for foreign mailing.

NBS Special Publication 305, Supplement 1, Publications of the NBS, 1968-1969. When ordering, include Catalog No. C13.10:305/Suppl. 1. Price $\$ 4.50 ; \$ 1.25$ additional for foreign mailing.

NBS Special Publication 305, Supplement 2, Publications of the NBS, 1970. When ordering, include Catalog No. C13.10:305/Suppl. 2. Price $\$ 3.25 ; 85$ cents additional for foreign mailing. 
U.S. DEPARTMENT OF COMMERCE

National Bureau of Standards

Washington, D.C. 20234

OFFICIAL BUSINESS

Penalty for Private Use, $\$ 300$
POSTAGE AND FEES PAIO U.S. OEPARTMENT OF COMMERCE 215 